\title{
THE NECESSITY OF BILINGUAL APPROACH IMPLEMENTATION AT HIGHER EDUCATIONAL ESTABLISHMENTS
}

\author{
Nataliia Martovytska \\ Bohdan Khmelnytsky National University of Cherkasy, Ukraine \\ Liubov Lokhvytska \\ Pereiaslav-Khmelnytskyi Hryhorii Skovoroda State Pedagogical University, Ukraine
}

\begin{abstract}
The article highlights the results of the bilingual approach implementation to the process of preparing students for their professional competencies in the context of higher education system reformation. The topicality of the study is caused by the fact that the entry of Ukrainian society into the European space imposes appropriate requirements for the new generation specialists' training. The purpose of the study was to substantiate theoretically and verify experimentally the implementation of a bilingual approach to learning a foreign language in the process of teaching some professional disciplines in order to improve the professional training of students of non-linguistic specialties. To achieve this goal, we used the following methods: to collect empirical survey data (student questionnaires and interviews with teachers), a statement experiment to find out the real state of the problem under investigation, a search experiment to implement the bilingual approach in the study of foreign language and its control. The experiment was participated by students of the $1^{\text {st }}$ and $2^{\text {nd }}$ years of study of non-linguistic specialties students at higher educational institutions during four terms, the study was carried out in three stages. At the first stage the level of preparation of the first-year students of non-linguistic specialties was studied. The results demonstrated that more than half of the respondents had difficulties in mastering the material. At the second stage of the study, a search experiment was conducted using a bilingual approach. In the course of the effectiveness approach checking, it was recorded that students demonstrated a sufficient level of foreign language proficiency due to the systematic use of the bilingual approach while studying basic disciplines.
\end{abstract}

Keywords: bilingual approach, communicative competence, foreign language, higher educational institution, language of professional orientation, motivation to study.

\section{Introduction}

In the last decade a change in the quality standards of education at all of its levels is taken place in Ukraine. It is concerned not only to secondary education but also to higher education (About Higher Education: The Law of Ukraine, 2014). The reason of such a process is the Ukrainian society's European integration, which, in its turn, requires the fluency of foreign languages. Since 
English is a basic language in any European society, it requires foreign language profficiency. Studying English is becoming relevant throughout the entire period of study, from the stage of studying it at high school, when the student acquires basic knowledge and skills, and continues to improve it at the professional level. However, in Ukraine, the last stage has a number of difficulties that are worth to be taken into consideration and overcoming of which requires immediate solution.

The aim of the study is to outline the theoretical basis of the scientific problem and to analyze the results of an empirical study of the bilingual approach effectiveness in teaching at HEI (higher educational institutions) while professional disciplines teaching for non-linguistic specialties.

To achieve the goal, the following tasks were set: 1) to reveal the essence of the bilingual approach learning process; 2) to characterize the foreign experience of this approach using; 3) to carry out an empirical verification of the effectiveness of the methodology of applying bilingual approach to raising the level of HEI students' professional communication skills.

\section{Methods and fundamentals of research}

Methodology of research - analysis, synthesis and review of sciencemethodical literature for a making comparative analysis of a different points of view on the problem being investigated; observation and questioning for students to find out the motivation in learning a foreign language, for teachers to determine the real state of teaching and mastering a foreign language by students, that is, the respondents were in a subject-subject relationship. Questionnaires were compliled by the authors to analyse the effectiveness of foreign language lessons and to determine the level of foreign language competent proficiency. Conducting searching experiment to determine the effectiveness of the bilingual approach application while teaching disciplines on their specialities at HEI.

Theoretical framework and methodology. The problem of foreign language profficiency at the level of fluent professional communication has emerged sharply recently, as the broadening of Ukraine's ties with European countries has led to an foreign investments increase to our country and, consequently, the demand for specialists who have knowledge and skills both in their specialty and speak foreign language fluently. Since the basic knowledge of a foreign language is obtained on the level of secondary education, so, the formation of foreign language competence on professional level is the prerogative of the HEI. The formation of a future specialist's foreign language professional competence enables him to be competitive in the labor market. The problem of teaching a foreign language as a component of multicultural 
communicative competence was the subject study of a number of Ukrainian researchers, in particular, in its psychological content (Balashov, Pasichnyk, \& Kalamazh, 2018; Spivak \& Kovalenko, 2018 and oths.), as well as pedagogical (Bihych, Borysko, \& Boretska, 2013; Borysova, 2016; Nikolaieva, 2013, 2015; Tarnopolskyi, 2010 and oths.). Among foreign authors, the search for the best ways to master the language was the subject of research of the following scientists as D. Brinton, M. Snow \& M. Wesche (1989); Y. Kyuchukov, O. Ushakova \& V. Yashina (2018) and oths. However, the peculiarities of bilingual approach implementation in the process of foreign languages study by students of non-linguistic specialties were not detailed there.

Thus, the scientific hypothesis of our study is that in order to achieve foreign language proficiency it is necessary to introduce a bilingual approach to the process of professional disciplines study at HEI.

\section{Results of theoretical research}

Substantiation of the use of the bilingual approach in the study of a foreign language. Bilingual education involves studying academic disciplines in two languages - native and foreign (Baker, 2011; Cohen, 1975; Gonzalez, 2015; Granados-Beltran, 2013; Kouega, 2008; Malarz, 1998; Pavon \& Gaustad, 2013; Porter, 1990 and oths.). In the XXI century, one-language professional communication insufficient for economic, social and educational progress. Modernization of society requires the several languages profficiency. Bilingual education is a peculiar system in which students with a low level of foreign language knowledge study subjects in both their mother tongue and foreign language. The generally accepted definition of bilingual education is "the use of two languages as a means of teaching a child or a group of children in part or all subjects according to the curriculum" (Cohen, 1975, 199).

Thus, in Cambridge, bilingual education is presented as follows (see diagram in Figure 1):

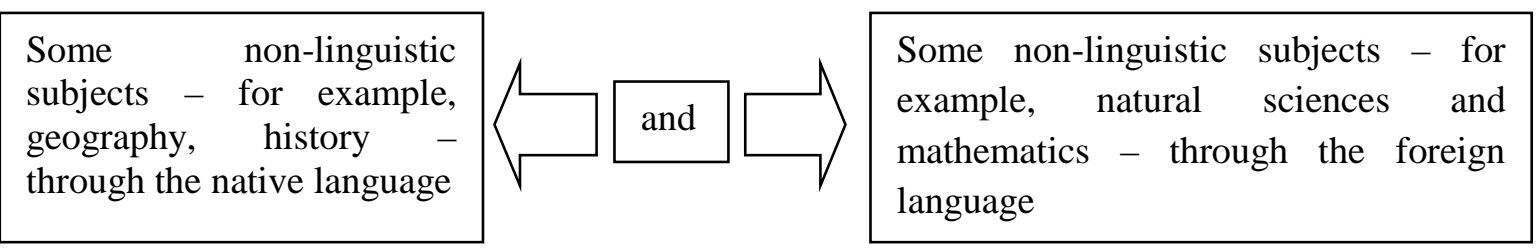

Figure 1 The structure of bilingual education at Cambridge (Cambridge, 2017, p.1)

And, as an alternative, the student has the opportunity to study the same subject in two languages (Cambridge, 2017, p.1). This approach is relevant in many European countries where English is not a national language, but demand 
in the labor market requires knowledge of English. European HEI practice this approach, motivating its application by the following criteria:

- cognition (divergent and creative thought development);

- foreign language proficiency on the level of certain specialty;

- literacy;

- knowledge gained in the native language can be freely transformed into different spheres of life (Malarz, 1998).

The outlined criteria are extremely relevant and important for young people in education in Ukraine.

Hence, we outline the working hypothesis of our study: the study of subjects applying the bilingual approach method will provide the opportunity for future specialists' foreign language further speech competence development; will focus on the subject itself and will increase the motivation to study it.

The results of the comparative analysis gave reasons for outlining such a generalization: on the basis of the handling of international experience materials, it was discovered that students who studied subjects on the basis of the bilingual approach did achieve progress and good results in mastering their mother tongue, foreign language, and the specialty discipline, as well gained a high level of professional competence. This technique enhances mental flexibility, improves intercultural skills and professionalism (Cambridge, 2017, p.2).

Problem statement. On the basis of scientific material systematization, it became clear that in the conditions of the Ukrainian higher education system, the above-mentioned advantages are difficult to achieve, since institutions of higher education face a number of obstacles. First, students are not motivated, as they study foreign language only as a basic course, which involves communication on everyday topics, usually only those that relate to everyday life. And obviously, while students do not face the real needs of foreign language communication at a professional level, they will not have the motivation to master foreign language. Secondly, the number of hours provided by the curriculum for the study of a foreign language is critically inadequate, which makes it impossible to master any foreign language at a high level. For example, in non-linguistic specialties, students have foreign language on average only once a week, which is studied only for two years (4 terms). The total number of hours allocated to classroom and independent study is only 240 hours per two years, of which the number of practical classes is only 96 hours. If we are talking about European integration, then the future the student is expected to face the need to communicate a foreign language, or to take an exam to determine the level of foreign language proficiency. According to the global scale (Nikolayeva, 2003, p.47), there are six levels of knowledge of a foreign 
language (A1-A2, B1-B2, C1-C2). Certainly, under such studyin process conditions, the level of foreign language proficiency can not be high.

If we take into account foreign experience, then in European countries faced the similar problem. It is said that in order to master at least B2, a student must have 500-600 hours of individual training (with a teacher), but in practice students have four hours per week, that is, sixty-four hours of a foreign language for the semester (Granados-Beltran, 2013, p.252). And the problem of the low level of students' proficiency in English when entering HEI is also relevant because, as in Ukraine, this level is lower than A2, which requires further additional training.

Thirdly, both in Ukraine and in European countries, there is another problem. In order to teach professional courses using a foreign language, the instructor should possess a fluent command of a foreign language and present the studying material on specialized disciplines in a foreign language only. However, as practice displays, the level of proficiency of teachers in a foreign language makes it impossible to develop the process outlined above. An English-speaking specialist in European countries did not have the experience of guidening a lecture on a particular subject due to difference of work schedule, workload, insufficient motivation, etc. (Granados-Beltran, 2013, p.253).

Partial hypothesis. In our opinion, at the initial stage of introducing a bilingual approach to the system of teaching specialist disciplines in a foreign language, the involvement of English-speaking specialists in HEI would be positive. Therefore, it is very important to prepare specialists who would be able to fill this gap in the educational process in HEI. Based on foreign experience, scholars and practitioners suggest using a basic foreign language course synchronously with bilingual courses in specialized disciplines. In particular, we share the scientific position of J. Gonzalez (2015), who emphasized in his research that this approach would expand the student's horizons and deepen their knowledge of English within the framework of future professional activities (Gonzalez, 2015).

Abroad has accumulated considerable experience in constructing a foreign language learning curriculum to acquire a sufficient level of knowledge (B2), including English language, subjects being taught in English, and additional classes (Baker, 2011; Kouega, 2008; Porter, 1990; Pavon \& Gaustad, 2013). Only under such conditions a student can achieve high results in mastering a foreign language of professional level (B2/C1) - this is yet another of the partial hypotheses. The demonstration above is presented in the diagram of fig. 2 (see figure 2). 


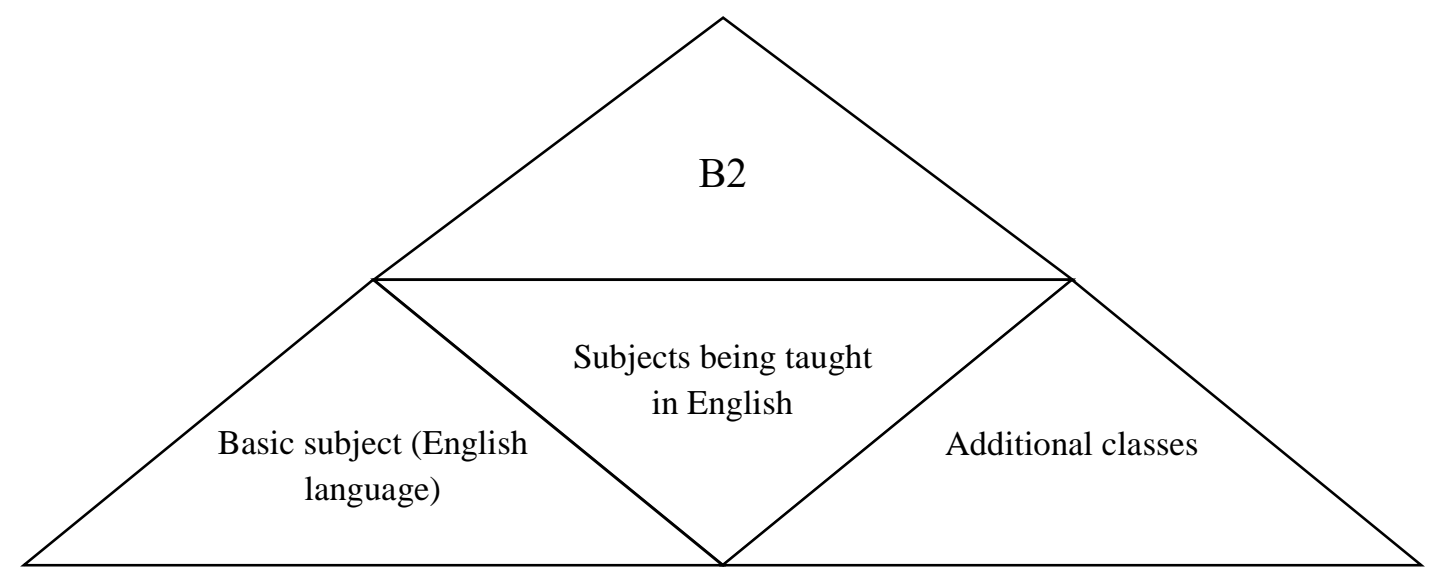

Figure 2 Language policy with a bilingual approach in Europe

To master the skills of language competence at a high level, different models of bilingual education are introduced. So, researcher C. Baker (2011) highlights the following models: transitional, supporting, enriched. Transitional model - does not involve the use of special language programs, students study in classes with teaching subjects in English. However, as the scientist argued, "this model significantly weakens the identity of minority children with their native language and culture of the family" (Baker, 2011, p.172). Supportive model aimed at studying the native language (of ethnic minorities), the bilingualism development and biculturality of students. Communicative competence is achieved through the study of two languages (native and foreign) (Baker, 2011, p.195). Enriched model, in turn, is aimed at achieving full bilingualism or a certain language competence (Baker, 2011, p.188-189).

\section{Results of empirical research}

Stages of research. Experimental research was carried out during 20142018 and was realized in three stages (2 times for 4 semesters for students of the 1-st and 2-nd yearsof study of non-linguistic specialties). Experiment covered 507 students who were studying in The Bohdan Khmelnytsky National University of Cherkasy and Pereiaslav-Khmelnytskyi Hryhorii Skovoroda State Pedagogical University.

On the first stage (2014-2015), the study of the state of foreign language students' training of non-linguistic specialties was conducted. On the basis of observations, the questioning of students of the 1st and 2nd year of study, the analysis of practical classes in the "Foreign language of professional orientation”, colleagues' classes attendance, the results of students' written works, the following facts were determined. 
The results of the empirical research showed that about $68 \%$ of students were able to independently master up to $20 \%$ of the material from the "Foreign language of professional orientation". At the same time, for $32 \%$ of respondents, this figure was only $7 \%$ or less. At the same time, during the experiment, we found out that $70 \%$ of its participants from the total number mastered the material during the classes in Foreign language of professional orientation at the level of deep awareness, although at the same time they adopted no more than $50 \%$ of the total amount of information, all the rest they write automatically. Only $7 \%$ of 1 st year students said that they are not usually prepared carefully for the test work (TW), if they were not informed about it in advance. However, this figure was somewhat higher and was $10 \%$ for the $2^{\text {nd }}$ year students.

In the course of the experiment, it was found out that $60 \%$ of students needed additional training, in particular, teacher's consultations after the TW. They, as it turned out, are not able to resolve their own faults in their own foreign language knowledge and skills. Only $4 \%$ of the respondents generally did not pay attention to the result of the TW, nor to the level of knowledge and did not desire to improve it. The data obtained also gave reasons for stating the following: $50 \%$ of the number of students who participated in the survey considered it necessary to attend at least one tutorial per week. Instead, 30\% indicated that they needed more additional utorials, because they did not have time to master the material that is nrcessaryto be prepared for practical classes. $23 \%$ of students stated that they were more complicated to perform homework than those offered in practical classes, and therefore had difficulty doing them on their own. Only $2 \%$ of the questioned respondents indicated that they were assisted by methodological recommendations (manuals, prepared by teachers) on the subject "Foreign language of professional orientation" during the homework and individual tasks implementation and preparation for the TW. All the rest of students noted that they only use lecture notes and examples of the tasks that they put together during the practical classes together with the whole group.

Of the total number of students who participated in the experiment, only $8 \%$ of respondents said that they never performed home and individual tasks on their own. But for most students, the implementation of such a kind of problem helped to generalize, systematize the listening educational material, consolidate the acquired knowledge and skills. In addition, it allowed, as noted by the respondents, to identify their own gaps and work extra (listening, grammar, vocabulary, etc.), in order to eliminate the shortcomings in time and not to let foreign-language studies into self-esteem. To the question: "What, in your opinion, prevents some students of your group from successfully passing the exam on the "Foreign language of professional orientation", 40\% indicated that they have a low level of knowledge, they've got at secondary school. 
Consequently, the results of the conducted students' questioning gave reasons to call to question the traditional approach to organizing the process of studying on the subject "Foreign language of professional orientation" in the HEI. This was due to the experimental application of the bilingual approach in teaching a foreign language for future specialists.

The analysis of psychological and pedagogical and scientific and methodological literature has shown that the bilingual approach is appropriate to consider as a relatively independent and rather important methodological approach to educational process organization, which gives the opportunity to take into account the specificity of each stage of the professional competence of future specialists' formation in non-linguistic specialties more fully. The obtained results gave reasons to formulate assumptions about the possibility of improving the professional training of students of non-linguistic specialties through the development and implementation of a bilingual approach in teaching of some specialty disciplines in the educational process.

At the first stage, the following directions of work were highlighted:

1) revealing the theoretical and methodological principles of improvement of language training of students in the process of foreign language teaching;

2) the development of methodological materials of bilingual content that would take into account the requirements of modern higher education, the personally oriented system of education, the requirements of individualization and differentiation of training that would not overburden teachers and students;

3) the search for such forms, methods and means of udying that would help to preserve and improve the quality of residual knowledge and skills of students and improve the efficiency of independent work of students, including through specially developed methodological materials of bilingual content.

Task of experimental research. Taking into account the results obtained, it was important to analyze in detail the current state of training of students "Foreign language of professional orientation" and the experience of teachers in organizing the process of studying professional disciplines in a foreign language, in particular, organizing the bilingual course of teaching a foreign language. Particular attention was needed to the analysis of teachers' experience concerning the formation of professional competencies of non-native speakers in foreign language classes, since this problem required the search for ways to solve it.

Teachers were asked to answer the question: "What methodological approaches are important in the formation of competent foreign language proficiency for students with different levels of academic achievement?” The 
SOCIETY. INTEGRATION. EDUCATION

Proceedings of the International Scientific Conference. Volume II, May $22^{\text {th }}-23^{\text {th }}$, 2020. 52-68

actual figures obtained during the conduct of questionnaires among tchers of HEI are given in table 1 (see table 1 ).

Table 1 Results of teachers' questionnaires (*conventional signs)

\begin{tabular}{l|c|c|c}
\hline \multicolumn{1}{c|}{ Methodical approaches } & Elementary level & $\begin{array}{c}\text { Intermediate } \\
\text { level }\end{array}$ & Advanced level \\
\hline Audio and visual & ++ & + & - \\
\hline Communicative & - & + & ++ \\
\hline Suggestive & ++ & + & - \\
\hline Audio and lingual & - & - & - \\
\hline
\end{tabular}

* ++ - is systematic, + - is carried out episodically, --is never carried out.

Thus, the following conclusions can be drawn: the results of the analysis of the experience of teachers of HEI's professional activity have shown that the process of their competent foreign language proficiency formation in the student's professional direction is mostly spontaneous, unplanned, and occurs episodically.

At the second stage (2015-2016), a search experiment was conducted. Special attention was paid to organizing and conducting classes in a foreign language using the bilingual approach. The need for such an adjustment is substantiated by the results of an empirical study of the relationship between the current assessment received by students in the process of conducting entry testing (ET-1) and the exams on the course "Foreign language of professional orientation" (this implies an assessment, which was received at the first attempt to pass the exam). The obtained data confirmed our assumptions about the dependence between the level of students' training in the "Foreign language" during school course and the successful training of a foreign language of professional orientation at HEI. The summary results are presented in table 2 (see table 2).

Table 2 The value of the correlation coefficient between the ET and exams from a "Foreign language of professional orientation"

\begin{tabular}{c|c|c|c|c}
\hline Levels & $\begin{array}{c}\mathbf{1}^{\text {st }} \text { term } \\
\text { examination }\end{array}$ & $\begin{array}{c}\mathbf{2}^{\text {nd }} \text { term } \\
\text { examination }\end{array}$ & $\begin{array}{c}\mathbf{3}^{\text {rd }} \text { term } \\
\text { examination }\end{array}$ & $\begin{array}{c}\mathbf{4}^{\text {th }} \text { term } \\
\text { examination }\end{array}$ \\
\hline $\begin{array}{c}0-59 \\
\text { (elementary) }\end{array}$ & 0,89 & 0,90 & 0,91 & 0,88 \\
\hline $\begin{array}{c}60-74 \\
\text { (pre-intermediate) }\end{array}$ & 0,85 & 0,65 & 0,61 & 0,6 \\
\hline $\begin{array}{c}75-90 \\
\text { (intermediate) }\end{array}$ & 0,89 & 0,76 & 0,70 & 0,72 \\
\hline $\begin{array}{c}\text { 91-100 } \\
\text { (upper-intermediate) }\end{array}$ & 0,87 & 0,82 & 0,8 & 0,78 \\
\hline
\end{tabular}


At the end of the second phase of the experiment, adjustments were made between incoming knowledge and skills of students who were trained using the bilingual approach. So, the second TW was conducted, certifying the existing section of knowledge and skills of students from a "Foreign language of professional orientation" (ET-2). The results obtained for the implementation of the TW are shown in fig. 3 (see figure 3). We emphasize that the segment of the educational process aimed at the formation of professional competence by means of a foreign language using a bilingual approach was only for those students who received less than 60 points for the first TW. Thus, only students from this subgroup should have written the TW again. Hence, we can generalize: the results obtained at the $2^{\text {nd }}$ stage of the experiment, the results of work with students give grounds to assert the effectiveness of the suggested fragment of the bilingual approach in the process of study.

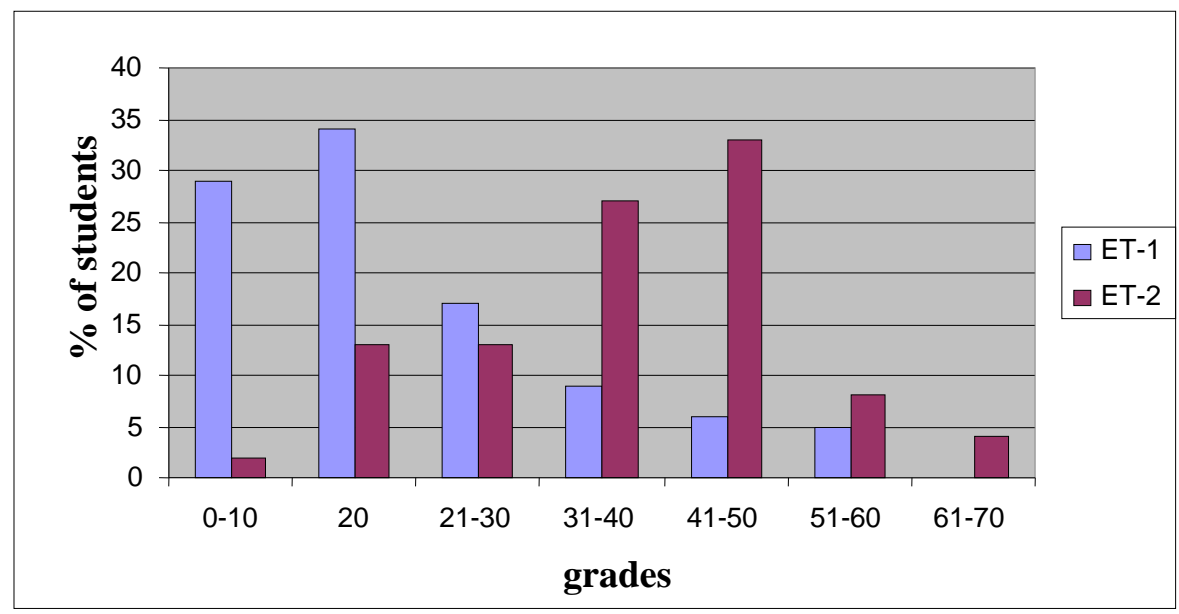

Figure 3 The results of the first and second entry testing

At the stage of the search experiment, the development of application in professional disciplines teaching using bilingual approach was carried out, aimed specifically at the formation and development of competent students' foreign language professional knowledge. This, in turn, should ensure an increase in the effectiveness of the study process as a whole. Through questionnaires, we were assured that students consider the introduction of a bilingual approach in the study process to be very useful and effective to use the acquired knowledge in their further professional activities. Therefore, we made the assumption that the implementation of the bilingual approach during classes on professional disciplines would increase the level of foreign language proficiency of students. Consequently, at the second stage of the experimental study, the testing of developed bilingual techniques was carried out and the search for the most effective forms of conducting classes from a foreign language for non-linguistic specialties was carried out. 
To test the effectiveness of the bilingual approach, 10 experimental groups (EG) were selected (251 students of the first year of specialties Social work, Preschool education, Fine Arts, Decorative Arts, Hotel and Restaurant Business, Tourism) and 10 control groups (CGs) (256 students of the 1-st year of the same specialties) (verification of the hypothesis about the normal distribution of the general totality from which the sample was performed was carried out according to the criterion $x^{2}$ using MathCad). The groups were selected so that the selective average academic success of the students in the CGs was not lower than that of the EG students. Academic success of the student was determined by the results of the incoming TW. Data is given in table 3 (see table 3).

Table 3 The results of the TW performed by CG and EG

\begin{tabular}{c|c|c|c|c|c|c|c}
\hline $\begin{array}{c}\text { Number } \\
\text { of CG }\end{array}$ & $\begin{array}{c}\text { Average } \\
\text { grade }\end{array}$ & $\begin{array}{c}\text { Sample } \\
\text { variance }\end{array}$ & $\begin{array}{c}\text { Quality } \\
\text { at \% }\end{array}$ & $\begin{array}{c}\text { Number } \\
\text { of EG }\end{array}$ & $\begin{array}{c}\text { Average } \\
\text { grade }\end{array}$ & $\begin{array}{c}\text { Sample } \\
\text { variance }\end{array}$ & $\begin{array}{c}\text { Quality } \\
\text { at \% }\end{array}$ \\
\hline 1 & 3,23 & 0,89 & 32,21 & 1 & 3,21 & 0,73 & 31,25 \\
\hline 2 & 3,12 & 0,82 & 30,57 & 2 & 3,15 & 0,89 & 30,45 \\
\hline 3 & 3,17 & 0,72 & 28,86 & 3 & 3,32 & 0,78 & 28,92 \\
\hline 4 & 3,31 & 0,74 & 31,47 & 4 & 3,05 & 0,62 & 25,62 \\
\hline 5 & 3,28 & 0,67 & 25,89 & 5 & 3,11 & 0,95 & 32,56 \\
\hline 6 & 3,09 & 0,58 & 28,65 & 6 & 3,24 & 0,83 & 33,59 \\
\hline 7 & 3,12 & 0,62 & 32,42 & 7 & 3,16 & 0,57 & 22,34 \\
\hline 8 & 3,1 & 0,83 & 31,25 & 8 & 3,3 & 0,64 & 30,89 \\
\hline 9 & 3,34 & 0,81 & 27,24 & 9 & 3,23 & 0,72 & 34,23 \\
\hline 10 & 3,25 & 0,61 & 29,67 & 10 & 3,05 & 0,91 & 27,56 \\
\hline $\begin{array}{c}\text { Average } \\
\text { value }\end{array}$ & $\mathbf{3 , 2 0 1}$ & $\mathbf{0 , 7 2 9}$ & $\mathbf{2 9 , 8 2 3}$ & $\begin{array}{c}\text { Average } \\
\text { value }\end{array}$ & $\mathbf{3 , 1 8 2}$ & $\mathbf{0 , 7 6 4}$ & $\mathbf{2 9 , 7 4 1}$ \\
\hline
\end{tabular}

After introduction suggested methodology of implementation the bilingual approach to the study of a foreign language during the first term of the educational process, we were able to determine the dynamics of changes in the average grades of achievement in the control and experimental groups. In the next diagram 4 (see figure 4), the average grade for students passing credit tests (CT) in a foreign language in the first (CT 1 - CT 11, CT 2 - CT 12) and the second academic semester (CT 1 - CT 21, CT 2 - CT 22), and, accordingly, examination control for the first (EC 1) and the second (EC 2) academic terms. We note that during the experiment, the value of sample dispersions in each of the control and experimental groups was investigated. The results obtained at this stage of the study showed that the dispersion indices in the control groups were almost unchanged, whereas in the experimental ones - dispersions were characterized by a decrease, although not significantly. Thus, we consider this fact as the one that, in the absence of a decrease of the average grade, it will cause an increase qualitative indicator level of academic achievements while 
studying the foreign language by students of experimental groups. At the same time, we note that the connection between the academic achievements of students in mastering a foreign language through the bilingual approach introduction, which was recorded during the execution of CT 12, CT 21, CT 22, and passing the EC 2, as a training material was taught by two languages, seems to be very significant. According to our scientific position, this is due to the fact that the interim control was verified during the implementation of the relevant control actions, which had a significant connection to the related subjects with the subject "The English language".

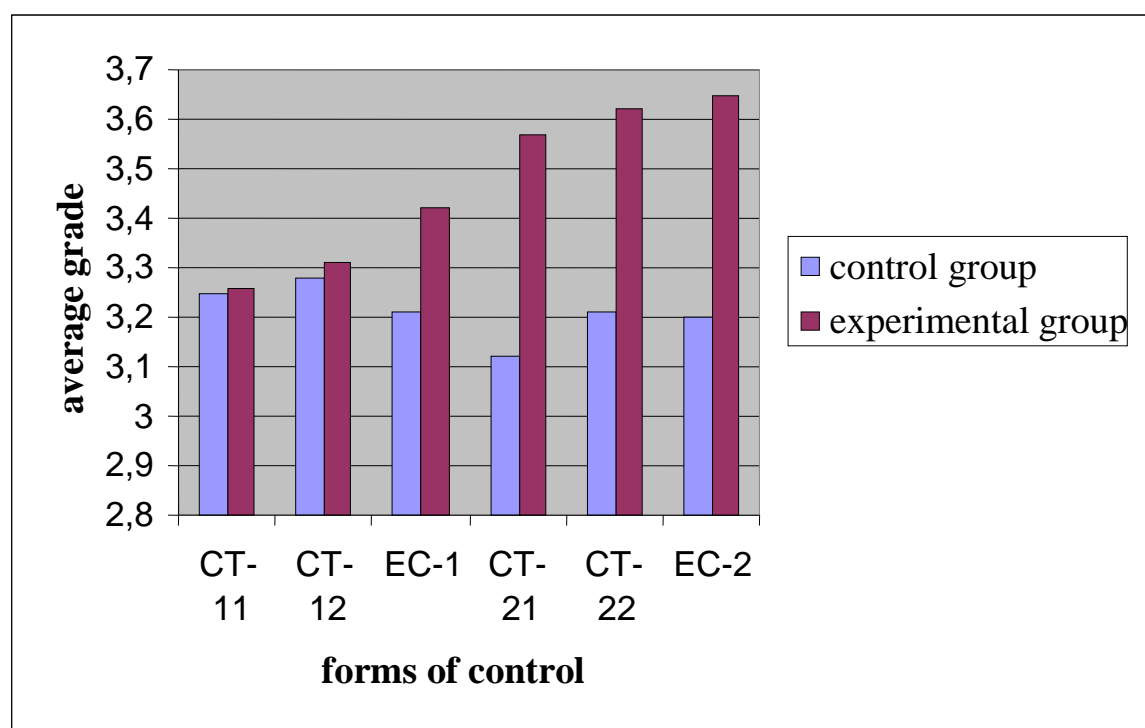

Figure 4 Average grades at CG and EG (based on the results of different forms of control)

On the basis of the result analysis, we made the following generalizations: the use of the bilingual approach in the study of a foreign language suggests that the tendency to increase the average grade in experimental groups is due to the influence of such a factor as the introduction into educational process of bilingual teaching of disciplines using the developed method. The reliability and probability confidence of this assumption can be achieved by using a one-factor dispersion analysis, the results of which indicate a positive impact on the foreign language teaching using bilingual approach developed by us. So, during the experiment, we focused on the indicator of maintaining the quality of residual knowledge and the formation of skills for students from the course of Foreign language of professional orientation in general. This led to the verification of the experimental results of the study. In particular, in the fifth academic term and at the beginning of the sixth term, rector's comprehensive test works on the discipline "Foreign Language" (RTW-5) were organized. The calculation of the average scores obtained by the students from the control and experimental 
SOCIETY. INTEGRATION. EDUCATION

Proceedings of the International Scientific Conference. Volume II, May $22^{\text {th }}-23^{\text {th }}$, 2020. 52-68

groups according to the results of the assessment of the knowledge recorded in the TW, compared with the average grade of the last exam on the course of "Foreign language of professional orientation" is given in table 4 (see table. 4).

Table 4 Changes of the average score of residual knowledge and skills of students on the course "Foreign language of professional orientation" in general (on the results of RTW)

\begin{tabular}{c|c|c|c|c|c|c|c}
\hline $\begin{array}{c}\text { CG } \\
\text { number }\end{array}$ & Exam & RTW-5 & RTW-6 & $\begin{array}{c}\text { EG } \\
\text { number }\end{array}$ & Exam & RTW-5 & RTW-6 \\
\hline 1 & 3,45 & 3,21 & 3,2 & 1 & 3,86 & 3,78 & 3,71 \\
\hline 2 & 3,62 & 3,34 & 3,18 & 2 & 3,57 & 3,54 & 3,48 \\
\hline 3 & 3,51 & 3,25 & 3,18 & 3 & 3,69 & 3,62 & 3,58 \\
\hline 4 & 3,25 & 3,12 & 3,04 & 4 & 3,89 & 3,81 & 3,76 \\
\hline 5 & 3,52 & 3,26 & 3,25 & 5 & 4,03 & 3,95 & 3,92 \\
\hline 6 & 3,27 & 3,11 & 3,1 & 6 & 4,08 & 3,92 & 3,89 \\
\hline 7 & 3,37 & 3,21 & 3,15 & 7 & 3,62 & 3,59 & 3,48 \\
\hline 8 & 3,31 & 3,09 & 3,12 & 8 & 3,81 & 3,76 & 3,68 \\
\hline 9 & 3,71 & 3,34 & 3,21 & 9 & 3,45 & 3,43 & 3,21 \\
\hline 10 & 3,45 & 3,32 & 3,25 & 10 & 3,61 & 3,58 & 3,14 \\
\hline $\begin{array}{c}\text { Average } \\
\text { value }\end{array}$ & $\mathbf{3 , 4 4 6}$ & $\mathbf{3 , 2 2 6}$ & $\mathbf{3 , 1 6 8}$ & $\begin{array}{c}\text { Average } \\
\text { value }\end{array}$ & $\mathbf{3 , 7 6 1}$ & $\mathbf{3 , 6 9 8}$ & $\mathbf{3 , 5 8 5}$ \\
\hline$N=507$ & & & & &
\end{tabular}

Based on the results obtained in the experimental (No. 9 and No. 10) groups during the second, third and fourth terms, mandatory credit test was canceled. In the table (see the digital indicators of the corresponding column), an average score based on the results of credit test is presented. For this reason, only about $5 \%$ of the total number of students in these experimental groups passed the exam. As a rule, these were students who demonstrated a low level of academic achievement in the discipline "Foreign language of professional orientation". Thus, if in the process of organizing the study of this discipline in the way of traditional teaching, the impact on the quality of the performance was not vivid (despite the slight increase in the high level of educational material mastering, which took place at a much slower pace than other experimental groups), the quality indicator of residual knowledge and the skills were vivid. Hence, we summarise that the influence of the use of the bilingual approach convincingly proves the necessity of teaching professional disciplines in a foreign language. In its turn, this greatly enhances the quality of obtaining, consolidating and preserving the results of training in this discipline and raises the level of students' professional language competence in a foreign language formation at a higher level. 


\section{Discussions}

Changes in the Ukrainian society as a whole and in the educational sphere in particular, led to a rethinking of goals, methods and approaches to learning. Especially this process has affected the level of tertiary education, what is reflected in a number of documents adopted at the state level (The Law of Ukraine: About Higher Education, 2014). This is due to the process of Eurointegration, taking place in the Ukrainian state, as well as due to not only new social needs, but also new high requirements for future specialists. Particularly acute was the issue of fluent foreign language proficiency by future specialists in order to increase their employability in the labor market (Lokhvytska, 2015, p.63; Martovytska, 2017, p.207; 2018, p.67).

The study of this issue on a global scale has made it possible to state that the scientific problem under study has, to a large extent, also become relevant to former colonies of the English-speaking countries or countries bordering the English-speaking countries, with ones EU members (France, Mexico, Spain and etc.). However, these countries have already gained some experience in its solution and have received relevant results and determined the direction of work in this field. In particular, V. Pavon and M. Gaustad (2013) were concerned with the designing bilingual programmes for higher education in Spain. In their work, they clearly identified the structural and organizational measures for the successful implementation of bilingual programs in the educational process of HEI.

The aforementioned recommendations were partly found in the study we proposed. At the same time, we would like to state that the scientific achievements of these scholars have a much wider range of applications, which should be implemented in the educational process of HEI of Ukraine. However, the application of the recommended methodology by the scientists (Pavon \& Gaustad, 2013) should pass the testing stage, taking into account the requirements for the developed state standards that will come into force in the nearest future in Ukraine.

We also see the peculiarity of the fact that the presented bilingual approach is characterized by certain difficulties for implementation into the educational process. The specification of the above is suggested in the scientific paper by C. Baker (2011), J.-P. Kouega (2008), R. Porter (1990), who have described in detail and identified as positiveindications, and drawbacks in the process of bilingual approach application. The outlined difficulties also occur the tertiary level of Ukraine, which is convincingly proved by the results of the research. However, taking into consideration, home and foreign experience, we have come to some conclusions that determine the benefits of an adequate 
implementation of a foreign language precisely because of the bilingual approach implementation in the educational process with students.

\section{Conclusions}

Thus, the essence of bilingual teaching approach is a combination of teaching basic subjects Foreign Language and of specialized subjects in a foreign language. This approach contributes to the development of cognitive thinking and increases the level of proficiency in a foreign language.

The given approach is used in European countries, which combines the basic subject of a foreign language with additional classes and separate professional disciplines, taught in a foreign language. With the systematic observance of all conditions and the continuity of the process, the application of this approach is effective.

We have found that students entering non-linguistic specialties in HEI have approximately the same level of language competence in a foreign language, and as practice shows, it is not high. Method of teaching professional subjects in the foreign language has been introduced into the curriculum and proved to be effective according to the experimental verification of its results. Thus, it significantly increases the level of students' communicative competence of a foreign language for special purposes.

However, a complete transition to bilingual education is a complex and lengthy process. This is, first of all, the lack of foreign-language specialists of certain disciplines on their specialities, a small number of academic hours of the basic discipline Foreign language for non-linguistic specialties, a gap in the study of a "Foreign language" at HEI, since students study this subject only 4 terms and continue studying it only in 9-10 academic terms.

The effectiveness of the basic subject "Foreign language of professional orientation" combined with the teaching professional disciplines in a specialty using foreign language is indisputable, since such an approach will ensure the further development of foreign language speech competence, focus on the subject and contribute to increasing the motivation of students to study it.

Perspectives for further scientific work are seen in the development of technology for retraining teachers to implement the bilingual approach in teaching disciplines on their specialities at the HEI.

\section{References}

About Higher Education: The Law of Ukraine. (2014). Verkhovna Rada of Ukraine: 1556VII, redaktsiya vid 01.01.2019. [Pro vyshchu osvitu: Zakon Ukrayiny: 1556-VII, 
Revision as of 01.01.2019]. Retrieved from http://zakon5.rada.gov.ua/laws/show/155618

Baker, C. (2011). Foundations of Bilingual Education and Bilingualism. Clevedon, UK: Multilingual Matters.

Balashov, E., Pasichnyk, I., \& Kalamazh, R. (2018). Samokontrol' ta samorehulyuvannya v protsesi rozuminnya tekstu studentamy universytetiv [Self-Monitoring and SelfRegulation of University Students in Text Comprehension]. Psiholingvistyka Psycholinguistics, 24(1), 47-62. doi.org/10.31470/2309-1797-2018-24-1-47-62

Bihych, O. B., Borysko, N. F., Boretska, H. E. et al. (2013). Metodyka navchannia inozemnykh mov i kultur: teoriia i praktyka [Methods of teaching foreign languages and cultures: theory and practice]. S. Iu. Nikolaieva (Ed.). Kyiv: Lenvit.

Borysova, N. V. (2016). Psykholinhvistychni osoblyvosti formuvannya komunikatyvnoyi kompetentsiyi profesiyno-oriyentovanoho chytannya $u$ studentiv nemovnykh spetsial'nostey [Psycholinguistic formation features of communicative competence of professionally oriented reading of the students of non-linguistic specialties]. Psiholingvistyka - Psycholinguistics, 19(1), 15-23.

Brinton, D. M., Snow, M. A., \& Wesche, M. B. (1989). Content-based second language instruction. Boston: Heinle \& Heinle Publishers.

Cambridge. (2017). Bilingual Learners and Bilingual Examinations. Cambridge Assessment International Journal. Retrieved from https://www.cambridgeinternational.org/ Images/271190-bilingual-learners-and-bilingual-education.pdf

Cohen, A. D. (1975). A Sociolinguistic Approach to Bilingual Education. Rowley, Mass., USA: Newbury House.

Gonzalez, J. A. (2015). Biligual Education Programmes at Higher Education (EMI: English Medium Introduction). Retrieved from https://www.slideshare.net/ JessngelGonzlez Lpez/bilingual-education-at-university-uc policy-plan-55748857

Granados-Beltran, C. (2013). Challenges of Bilingualism in Higher Education: The Experience of the Languages Department at the Universidad Central in Bogotá, Colombia. Gist Education and Learning Research Journal, 7, 245-258. Retrieved from https://files.eric.ed.gov/fulltext/EJ1062582.pdf

Kouega, J.-P. (2008). Bilingualism at Tertiary Level Education in Cameroon: The Case of the University of Yaounde II (Soa). ISB6: Proceedings of the 6th International Symposium on Bilingualism (30 May - 2 June, 2007, University of Hamburg). Retrieved from http://archiv.gwin.gwiss.uni-hamburg.de/isb6/proceedings/kouega.pdf

Kyuchukov, H., Ushakova, O., \& Yashina, V. (2018). Sotsial'no-kul'turni aspekty ovolodinnya movoyu $\mathrm{v}$ protsesi spilkuvannya [Socio-Cultural Aspects of Language Acquisition Through Conversation]. Psiholingvistyka - Psycholinguistics, 23(1), 189-201. doi.org/10.5281/zenodo. 1217897

Lokhvytska, L. (2015). Reformuvannya natsional'noyi vyshchoyi osvity na yevropeys'kykh zasadakh: opanuvannya pol's'koho dosvidu [Reform of the national higher education on European principles: mastering the Polish experience]. Ridna shkola, 11-12, 61-65.

Malarz, L. (1998). Bilingual Education: Effective Programming for Language-Minority Students. Curriculum Handbook. Retrieved from http:/www.ascd.org/publications/ curriculum_handbook/413/chapters/Bilingual_Education@_Effective_Programming_fo r_Language-Minority_Students.aspx

Martovytska, N. V. (2017). Formuvannya profesional'noyi anhlomovnoyi kompetentsiyi studenta za dopomohoyu kart pam"yati [Formation of professional English competence 
of the student with the help of memory cards]. In S. P. Arkhypovoyi (Red.), Suchasna nauka i osvita: novi realiyi i naukovi rishennya (pp. 207). Cherkasy: FOP Hordiyenko Ye. I.

Martovytska, N. V. (2018). Osoblyvosti vykladannya inozemnoyi movy studentam nemovnykh spetsial'nostey u vyshchykh navchal'nykh zakladakh [Features of Teaching Foreign Language for Students of Non-Linguistic Specialities at Higher Educational Establishments]. Visnyk Cherkas'koho universytetu. Seriya «Pedahohichni nauky». (Vol. 1, pp. 64-69). Cherkasy.

Nikolaieva, S. Yu. (Ed.). (2015). Suchasni tekhnolohii navchannia inozemnykh mov i kultur u zahalnoosvitnikh vyshchykh navchalnykh zakladakh [Modern teaching technologies of foreign languages and cultures in general and higher educational establishments]. Kyiv: Lenvit.

Nikolayeva, S. Yu. (Ed.). (2003). Zahal'noyevropeys'ki Rekomendatsiyi z movnoyi osvity: vyvchennya, vykladannya, otsinyuvannya [Common European Framework of Reference for Languages: Learning, Teaching and Assessment]. Pereklad. z anhl. Kyiv: Lenvit.

Pavon, V., \& Gaustad, M. (2013). Designing Bilingual Programmes for Higher Education in Spain. Organisational, Curricular and Methodological Decisions. International CLIL Research Journal, 2(1), 82-94. Retrieved from http://www.icrj.eu/21/article7.html

Porter, R. P. (1990). Forked tongue: the politics of bilingual education. New York: Basic Books.

Spivak, L., \& Kovalenko, O. (2018). Mova spilkuvannya yak umova rozvytku natsional'noyi identychnosti students'koyi molodi [Language of Communication as an Important Condition for the Development of National Identity During Ukrainian Students]. Psiholingvistyka - Psycholinguistics, 24(1), 304-319. doi.org/10.31470/2309-17972018-24-1-304-319

Tarnopolskyi, O. B. (2010). Eksperiyentsiyno-interaktyvne navchannya inozemnoyi movy dlya spetsial'nykh tsiley u nemovnomu VNZ: sutnist' pidkhodu [Experiential-interactive foreign language learning for special purposes in non-formal university: the essence of the approach]. Vykladannya mov u VNZ osvity na suchasnomu etapi. Mizhpredmetni zv"yazky, 17, 125-133. 